Article

\title{
The Inhibitory Effect of Plant Extracts on Growth of the Foodborne Pathogen, Listeria monocytogenes
}

\author{
Marina Ceruso ${ }^{1}$, Jason A. Clement ${ }^{2}$, Matthew J. Todd ${ }^{2}$, Fangyuan Zhang ${ }^{3}$, Zuyi Huang ${ }^{3}$, \\ Aniello Anastasio ${ }^{1}$, Tiziana Pepe ${ }^{1}$ and Yanhong Liu ${ }^{4, * \mathbb{D}}$ \\ 1 Department of Veterinary Medicine and Animal Production, University of Naples Federico II, 80100 Naples, \\ Italy; marina.ceruso@unina.it (M.C.); aniello.anastasio@unina.it (A.A.); tiziana.pepe@unina.it (T.P.) \\ 2 Natural Products Discovery Institute, Baruch S. Blumberg Institute, 3805 Old Easton Rd., Doylestown, \\ PA 18960, USA; jason.clement@bblumberg.org (J.A.C.); matthew.todd@bblumberg.org (M.J.T.) \\ 3 Department of Chemical and Biological Engineering, Villanova University, Villanova, PA 19085, USA; \\ fzhang@villanova.edu (F.Z.); zuyi.huang@villanova.edu (Z.H.) \\ 4 Eastern Regional Research Center, Agricultural Research Service, U.S. Department of Agriculture, \\ 600 East Mermaid Lane, Wyndmoor, PA 19038, USA \\ * Correspondence: yanhong.liu@usda.gov; Tel.: +1-215-233-6587; Fax: +1-215-233-6581
}

Received: 29 May 2020; Accepted: 9 June 2020; Published: 11 June 2020

\begin{abstract}
Listeria monocytogenes is a foodborne pathogen responsible for about 1600 illnesses each year in the United States (US) and about 2500 confirmed invasive human cases in European Union (EU) countries. Several technologies and antimicrobials are applied to control the presence of L. monocytogenes in food. Among these, the use of natural antimicrobials is preferred by consumers. This is due to their ability to inhibit the growth of foodborne pathogens but not prompt negative safety concerns. Among natural antimicrobials, plant extracts are used to inactivate L. monocytogenes. However, there is a large amount of these types of extracts, and their active compounds remain unexplored. The aim of this study was to evaluate the antibacterial activity against L. monocytogenes of about 800 plant extracts derived from plants native to different countries worldwide. The minimal inhibitory concentrations (MICs) were determined, and scanning electron microscopy (SEM) was used to verify how the plant extracts affected L. monocytogenes at the microscopic level. Results showed that 12 of the plant extracts had inhibitory activity against L. monocytogenes. Future applications of this study could include the use of these plant extracts as new preservatives to reduce the risk of growth of pathogens and contamination in the food industry from L. monocytogenes.
\end{abstract}

Keywords: cell damage; Listeria monocytogenes; plant extracts; food safety

\section{Introduction}

Listeriosis is a disease caused by the foodborne pathogen Listeria monocytogenes. It is assessed to cause about 1600 illnesses each year in the United States (US), and about 2500 confirmed invasive human cases were reported in European Union (EU) countries [1,2], with a high mortality rate of about $20 \%$ in at-risk populations. A wide variety of foods, including meat, dairy products, and fresh produce, are associated with outbreaks of listeriosis. L. monocytogenes is able to survive and grow in harsh environmental conditions such as high salt concentration, low $\mathrm{pH}$, and low temperature. This characteristic increases its potential for contamination and growth on food products and poses some challenges for control [3-5]. Thus, the presence of L. monocytogenes in foodstuffs is still considered a major food safety problem worldwide [6]. Several technologies and antimicrobials are applied to control L. monocytogenes. Use of natural antimicrobials is preferred by consumers, particularly when compared with synthetic preservatives. This is due to their ability to inhibit the growth of foodborne 
pathogens but not prompt negative safety concerns [7]. Among natural antimicrobials, plant extracts are used to inactivate L. monocytogenes [8-10]. However, there is a large amount of these types of plant extracts, and their active compounds remain largely unexplored. Therefore, there is the need to expand our knowledge about the types and doses of plant extracts useful as antimicrobials for controlling important foodborne pathogens such as L. monocytogenes. The aim of this study was to evaluate the antibacterial activity against $L$. monocytogenes strain F2365 of about 800 extracts derived from plants native to different countries from all over the world. Results showed that 12 of the plant extracts had inhibitory activity against $L$. monocytogenes. Scanning electron microscopy (SEM) was used to examine the effects of the extracts on L. monocytogenes at the microscopic level. The discovery of new natural antimicrobials could have different applications in the food industry, such as for treatments with new, more effective preservatives/antimicrobials or for the enhancement of those currently used, as well as for the formulation of innovative packaging materials.

\section{Results}

\subsection{Effect of Plant Extract on Growth of L. monocytogenes and Determination of Minimum Inhibitory} Concentrations (MICs)

In total, 780 plant extracts were used to test the growth inhibition in L. monocytogenes. These plant extracts are from plants found worldwide and, moreover, different parts (leaves, root, twigs, etc.) of some plants were also included. Twelve plant extracts were shown to inhibit the growth of L. monocytogenes. The identity of the plants and the MICs obtained are shown in Table 1.

With regard to the families of the 12 extracts, it is interesting to note that three out of the 12 were derived from different species of the same family of Fabaceae (Baphia racemosa, Desmodium adscendens, and Eriosema preptum), and the rest were derived from different families. Regarding the geographic origin, $50 \%$ of the 12 extracts were derived from plants from South Africa, $25 \%$ from the Republic of Georgia, and 25\% from the US. No hit was obtained from extracts from Puerto Rico, but a very small portion of the tested plant extracts (15 of 780) had this geographic origin. With regard to the MICs, Baphia racemosa and Sansevieria hyacinthoides showed the lowest value of MICs ( $2.5 \mathrm{mg} / \mathrm{mL})$ followed by Passiflora foetida, Desmodium adscendens, Salvia nemorosa, Alnus barbata, and Botrychium multifidum at the MIC values of $5 \mathrm{mg} / \mathrm{mL}$. The species Trichilia emetica, Eriosema preptum, Darlingtonia californica, Proboscidea louisianica, and Sambucus ebulus had MIC values of $10 \mathrm{mg} / \mathrm{mL}$. 
Table 1. The 12 plant extracts with antibacterial effect against Listeria monocytogenes F2365. MIC—minimum inhibitory concentration; USA-United States of America.

\begin{tabular}{|c|c|c|c|c|c|c|c|}
\hline Group & No. & Family & Genus & Species & Extraction Origin (Plant Part) & Geographicorigin & $\mathrm{MIC}(\mathrm{mg} / \mathrm{mL})$ \\
\hline \multirow{5}{*}{ A } & 1 & Meliaceae & Trichilia & emetica & Leaves & South Africa & 10 \\
\hline & 2 & Passifloraceae & Passiflora & foetida & Whole plant & South Africa & 5 \\
\hline & 3 & Lamiaceae & Salvia & nemorosa & Whole plant & Georgia & 5 \\
\hline & 4 & Sambucaceae & Sambucus & ebulus & Whole plant & Georgia & 10 \\
\hline & 5 & Fabaceae & Baphia & racemosa & Root & South Africa & 2.5 \\
\hline \multirow{3}{*}{ B } & 6 & Dracaenaceae & Sansevieria & hyacinthoides & Root & South Africa & 2.5 \\
\hline & 7 & Fabaceae & Desmodium & adscendens & Whole plant & South Africa & 5 \\
\hline & 8 & Fabaceae & Eriosema & preptum & Whole plant & South Africa & 10 \\
\hline \multirow{4}{*}{$\mathrm{C}$} & 9 & Sarraceniaceae & Darlingtonia & californica & Leaves & USA & 10 \\
\hline & 10 & Pedaliaceae & Proboscidea & louisianica & Seed pod & USA & 10 \\
\hline & 11 & Betulaceae & Alnus & barbata & Leaves + twigs & Georgia & 5 \\
\hline & 12 & Ophioglossaceae & Botrychium & multifidum & Root & USA & 5 \\
\hline
\end{tabular}




\subsection{Scanning Electron Microscopy (SEM)}

The morphology of L. monocytogenes F2365 cells treated with the 12 plant extracts $(10 \mathrm{mg} / \mathrm{mL})$ was observed using SEM. The untreated L. monocytogenes cells showed a normal cell morphology, with a typical short rod shape, intact cell structure, a smooth and compact surface, and flagella (Figures 1C, $2 \mathrm{C}$ and $3 \mathrm{C}$ ). After treatment at $30{ }^{\circ} \mathrm{C}$ for $24 \mathrm{~h}, \mathrm{~L}$. monocytogenes cells showed loss of flagella in all of the samples. Treatment with seven out of the 12 plant extracts showed consistently damaged L. monocytogenes cells (Figures 1-3). In particular, the cells showed morphological damage such as detachment of the cytoplasmic membrane from the cell wall, leakage of intracellular components, and severe cell collapse and deformation. The effect of No. 2 plant extract (Passiflora foetida) was peculiar. Only for this extract, there was the creation of holes in the external wall of the bacteria. Extract No. 12 (Botrychium multifidum) had a very strong effect on L. monocytogenes cells that were practically destroyed. Meanwhile, the cells of L. monocytogenes treated with extract No. 1, 4, 5, 7, and 8 shown in Figures 1-3 displayed minor damage. Table 2 reports a summary of the SEM results.

Table 2. Summary of the results obtained by SEM observations of the bacterial cells.

\begin{tabular}{|c|c|c|c|c|c|}
\hline Group & No. & Genus & Species & $\mathrm{MIC}(\mathrm{mg} / \mathrm{mL})$ & Cell Damage (SEM) \\
\hline \multirow{3}{*}{ A } & 1 & Trichilia & emetica & 10 & Loss of flagella \\
\hline & 2 & Passiflora & foetida & 5 & $\begin{array}{l}\text { Loss of flagella, holes in the external } \\
\text { bacteria wall }\end{array}$ \\
\hline & 3 & Salvia & nemorosa & 5 & $\begin{array}{c}\text { Loss of flagella, severe cell collapse } \\
\text { and deformation }\end{array}$ \\
\hline \multirow{5}{*}{ B } & 4 & Sambucus & ebulus & 10 & Loss of flagella \\
\hline & 5 & Baphia & racemosa & 2.5 & Loss of flagella \\
\hline & 6 & Sansevieria & hyacinthoides & 2.5 & Loss of flagella, cell deformation \\
\hline & 7 & Desmodium & adscendens & 5 & Loss of flagella \\
\hline & 8 & Eriosema & preptum & 10 & Loss of flagella \\
\hline \multirow{4}{*}{$\mathrm{C}$} & 9 & Darlingtonia & californica & 10 & $\begin{array}{c}\text { Loss of flagella, severe cell collapse } \\
\text { and deformation }\end{array}$ \\
\hline & 10 & Proboscidea & louisianica & 10 & $\begin{array}{l}\text { Loss of flagella, leakage of } \\
\text { intracellular components }\end{array}$ \\
\hline & 11 & Alnus & barbata & 5 & $\begin{array}{l}\text { Loss of flagella, severe cell collapse } \\
\text { and deformation }\end{array}$ \\
\hline & 12 & Botrychium & multifidum & 5 & Cell destruction \\
\hline
\end{tabular}
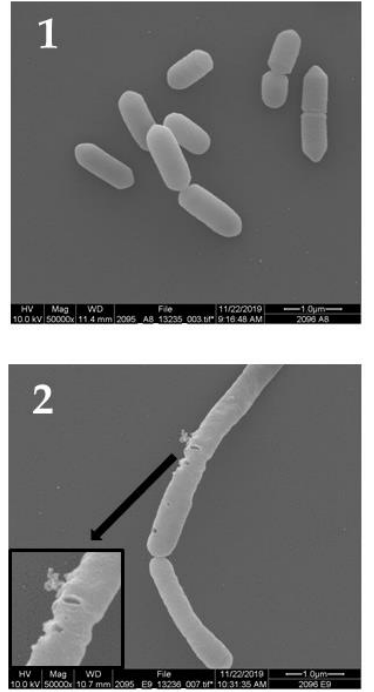
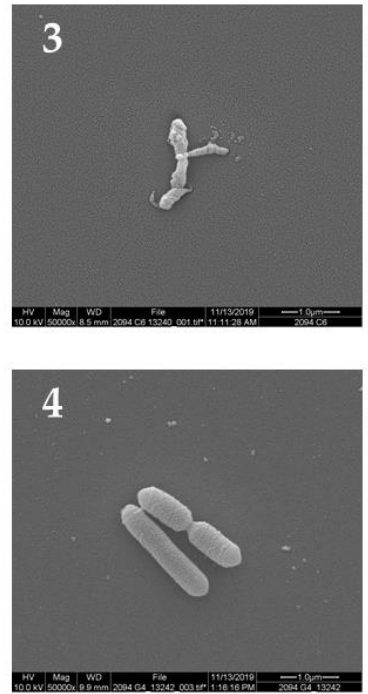

Figure 1. Morphology of L. monocytogenes F2365 cells treated with plant extracts No. (1-4) (group A) observed using SEM, in comparison with L. monocytogenes F2365 that was not treated with samples-control (C). White arrows show flagella in (C). The black arrow shows pores in the cell membrane. Number/plant species correspondence is shown in Table 1. 

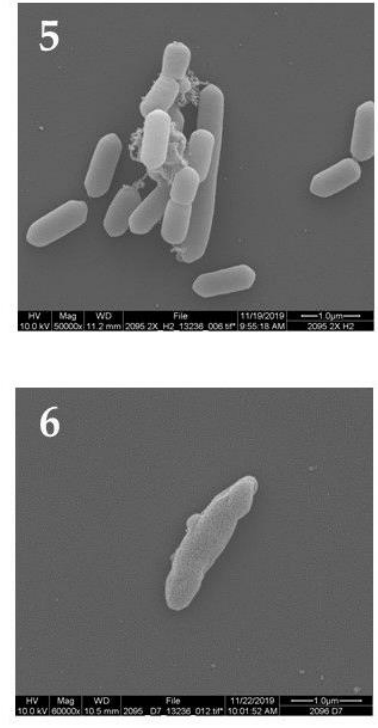
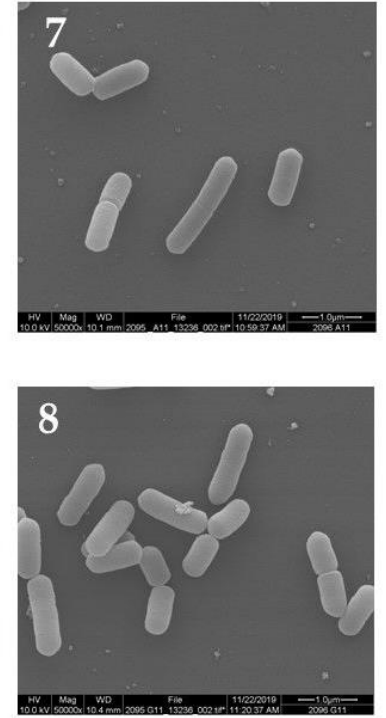

Figure 2. Morphology of L. monocytogenes F2365 cells treated with the plant extracts No. (5-8) (group B) observed using SEM, in comparison with L. monocytogenes F2365 that was not treated with samples—control (C). White arrows show flagella in (C).
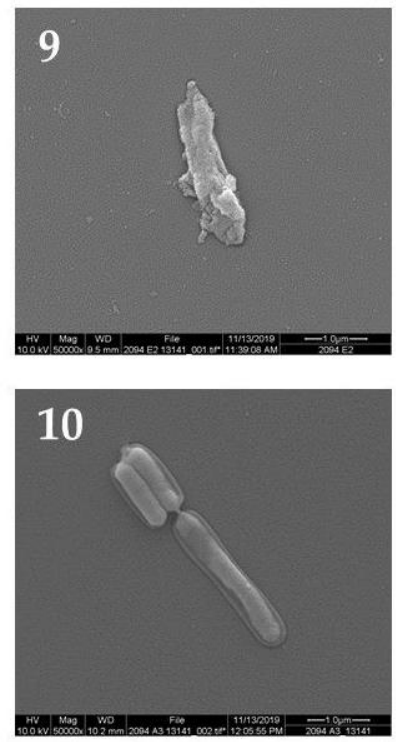
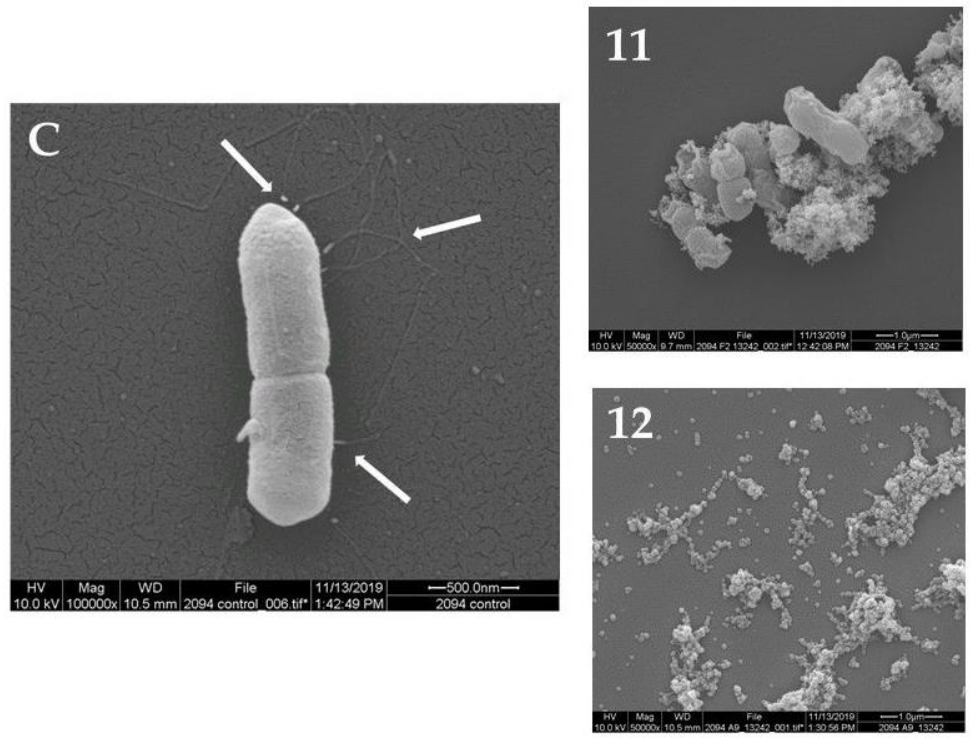

Figure 3. Morphology of L. monocytogenes F2365 cells treated with the plant extracts No. (9-12) (group C) observed using SEM, in comparison with L. monocytogenes F2365 that was not treated with samples—control (C). White arrows show flagella in (C).

\section{Discussion}

In this paper, the potential antibacterial activity of an extraordinarily vast collection of plant extracts was explored against the foodborne pathogen L. monocytogenes. This collection included extracts from plants found all over the world and including different parts of the plant. Furthermore, the extracts were separated by different solvents based on polarity (polar: methanol, dichloromethane; non-polar: hexane), which makes further fractionation/separation much easier.

This research provides an expansion of knowledge on the antibacterial properties of plant extracts and identified 12 new anti-Listeria plant extracts. None of these extracts, to our knowledge, were tested before for anti-listerial behavior. Considering the activities identified in previous research, we can separate our 12 plant extracts as belonging to three groups of plants: A-plants already used 
with medical application, showing antimicrobial activities against other bacteria; B-plants with other medical functions but not antibacterial; C-plants that previously never showed any antimicrobial activities or medical applications.

The A group includes Trichilia emetica, Passiflora foetida, Salvia nemorosa, and Sambucus ebulus. T. emetica (plant extract No. 1) previously showed hepatoprotective and antibacterial activity, including action against Staphylococcus aureus [11], and it was also involved in malaria control [12]. P. foetida is a wild species commonly used for the treatment of hysteria, asthma, skin diseases with inflammation [13], and for many other anti-inflammatory and analgesic activities [14]. It also showed an antibacterial effect, e.g., against Escherichia coli HB 101, Streptococcus pyogenes, and Bacillus thuringiensis strains [15,16]. $S$. nemorosa deserves special mention since it gave very good results against L. monocytogenes in this study (Table 2). Several species of the genus Salvia are known for their uses as additives in food products [17-19]. The extract obtained from the species S. nemorosa was never previously tested against L. monocytogenes but appeared to have good antibacterial activity against other foodborne pathogens [20]. The last plant of this group is Sambucus ebulus (plant extract No. 11), and it has several clinical applications [21,22], with anti-inflammatory components of the leaves [23] and antioxidant activity of the flowers [24,25]. Its methanolic extract had antimicrobial activity against S. aureus [26,27].

Plants belonging to the B group are Baphia racemose, Sansevieria hyacinthoides, Desmodium adscendens, and Eriosema preptum. B. racemose (our plant extract No. 2) showed in previous research a specific inhibition effect on human liver $\beta$-D-glucuronidase and $\alpha$-L-iduronidase [28]. S. hyacinthoides (plant extract No. 3) is one of the most promising extracts against L. monocytogenes identified in this study. Most members of Sansevieria are of great economic importance as ornamentals [29], but S. hyacinthoides is also used in traditional African medicine. Leaves and rhizomes of the plant are squeezed, and the juice is used in the treatment of ear infections, toothaches, ulcers, intestinal worms, stomach disorders, and diarrhea [30]. It also can be used to treat snake bites [31-33]. However, no use is made of this plant, as far as we know, in food hygiene, and our results show that its use warrants further investigation. In the current research, $S$. hyacinthoides showed good results for L. monocytogenes growth inhibition and a low MIC of $2.5 \mathrm{mg} / \mathrm{mL}$, and it induced damage to bacterial cells observed with SEM (Figure 2). The B. racemose and S. hyacinthoides extracts gave the same results in regard to L. monocytogenes growth inhibition and MIC, but the effect on the bacterial cells observed using SEM appeared less obvious for the B. racemose extract, since only flagella were lost. Regarding plant extract No. 5, an ethanol extraction of D. adscendens had antipsychotic-like activities in mice [34]. E. preptum is the plant species of No. 6 extract. Several Eriosema (Fabaceae) species are a good source of flavonoids with pharmacological activities [35,36], but no anti-bacterial activities were reported for the E. preptum species.

Finally, the $\mathrm{C}$ group comprises plants that, to our knowledge, did not previously demonstrate antimicrobial activities or medical applications; however, antibacterial potential was observed for the first time in in this study through their good anti-listerial activity. The species with these features were Darlingtonia californica, Proboscidea louisianica, Alnus barbata, and Botrychium multifidum. D. californica belongs to Sarraceniaceae, a carnivorous plant family, endemic to southern Oregon and northern California, United States of America (USA) [37]. Devil's claw (P. louisianica) is basically grown as an ornamental plant all over the world (USA, Africa, Australia, Europe) and is a source of essential oil [38]. A. glutinosa subsp. barbata is found in various countries, including Turkey and Iran, and it is common to the Colchis forests of Georgia [39]. There are no reported uses of this taxon. B. multifidum is a fern native to California, also found elsewhere in North America and beyond, with no particular use or trades. This group of plant extracts warrants further investigation.

With regard to the mechanism of action of the plant extracts, it is known that plant polyphenols play important roles in plant defense mechanisms against bacteria, viruses, and fungi, and that they are the major components of plant extracts [40,41]. Plants belonging to group A in the current study were reported to have antibacterial activity mainly due to the presence of polyphenols $[11,16,18,26,42]$, and their use was described as potential natural preservatives for the food industry $[40,41,43-45]$. The mechanism of bacterial inhibition by polyphenols is complex. They can act by chelating iron, 
which is important for the survival of many bacteria [46]. They also work together with nonspecific forces, producing an effect on microbial membranes, adhesins, enzymes, and cell envelope transport proteins, and polyphenols interact with proteins and/or phospholipids from the lipid bilayer, increasing membrane permeability, modifying ion transport processes, and damaging cell membranes [47-54]. Polyphenols may also induce irreversible changes in E. coli, Pseudomonas aeruginosa, S. aureus, and L. monocytogenes membranes, causing rupture and pore formation with leakage of intracellular constituents [55]. Furthermore, polyphenols inhibit bacterial motility through loss of flagella [41,56], and they can inhibit biofilm formation [41,57]. For example, polyphenols from olive leaves and olive mill wastes were shown to reduce expression of motility- and biofilm-related genes in E. coli [58].

Food-related applications for these plant extracts could be for the formulation of new food preservatives and sanitizers for the food processing environment, as well as for the development of innovative food packaging. The MIC values in the $\mathrm{mg} / \mathrm{mL}(\mathrm{g} / \mathrm{L})$ range are typical for plant extracts since they contain a mixture of active and non-active compounds. For example, olive leaf extract that has antimicrobial activities had a MIC of $62.5 \mathrm{mg} / \mathrm{mL}$ for L. monocytogenes [57,59]. In terms of application in food, the extracts or their active compounds can be used in combination with other antimicrobials to achieve synergistic effects. Moreover, their MICs could be further reduced if they are used as nanowires [59].

In the current study, inhibition of L. monocytogenes seemed compatible with the described effects caused by plant polyphenols, since there was inhibition of bacterial growth, cell membrane damage, and pore formation with some extracts, and, in all cases, there was loss of flagella (Table 2). Future directions will focus on fractionation of the 12 plant extracts to reveal their active compounds. No toxicities of these plants are yet reported. Once the active compounds in the extracts are identified, their toxicities should be determined using mouse models to define the safe dose. In addition, the cytotoxicity, mutagenicity, and genotoxicity of the plant extracts should also be investigated.

In addition, gene expression analyses of L. monocytogenes exposed to these plant extracts may reveal their potential effects on virulence-related genes of L. monocytogenes to determine if there could be a decrease in virulence of $L$. monocytogenes with exposure to the extracts or the active compounds.

\section{Materials and Methods}

\subsection{Plant Extracts and Crude Fractionation}

All of the plant families tested in this study are shown in Figure 4.

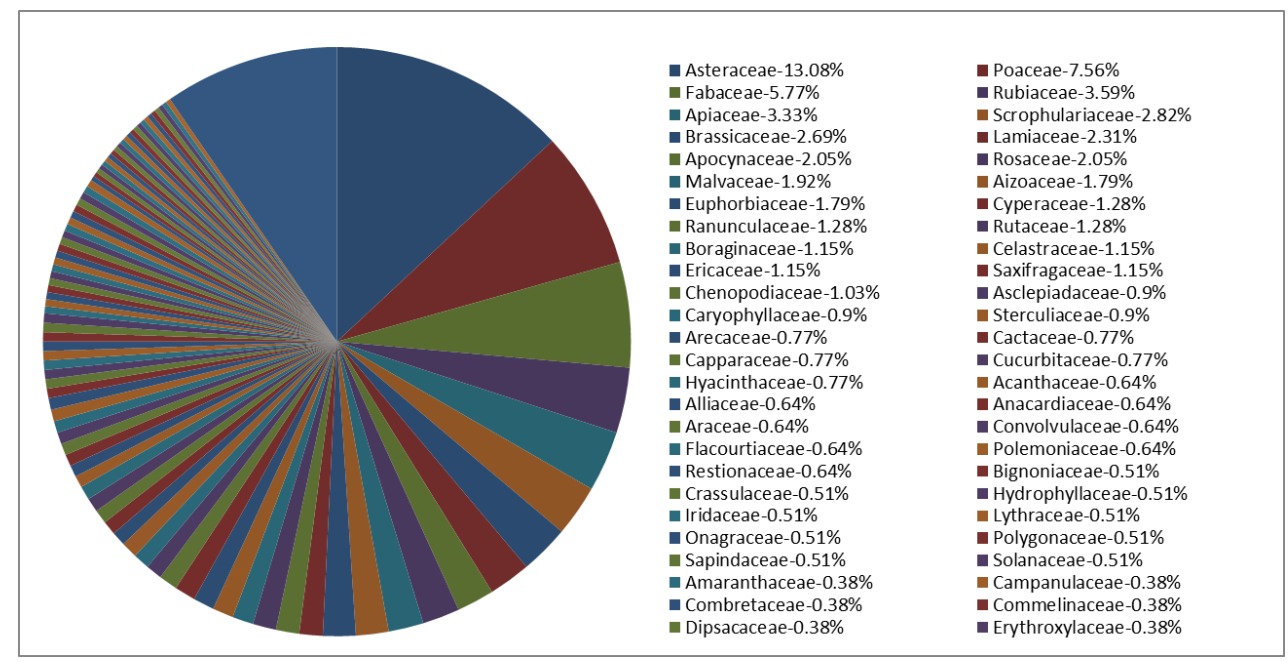

Figure 4. Families of the plants and respective percentage of use in this study. 
The plant extracts tested in this study were supplied and identified by the Natural Products Discovery Institute, Baruch S. Blumberg Institute, Doylestown, Pennsylvania, USA. The extracts were prepared from specimens of $n=780$ plant species representing $n=326$ plant species from the Republic of South Africa, $n=285$ from the US, $n=154$ plant species from the Republic of Georgia, and $n=15$ from Puerto Rico (Figure 5).

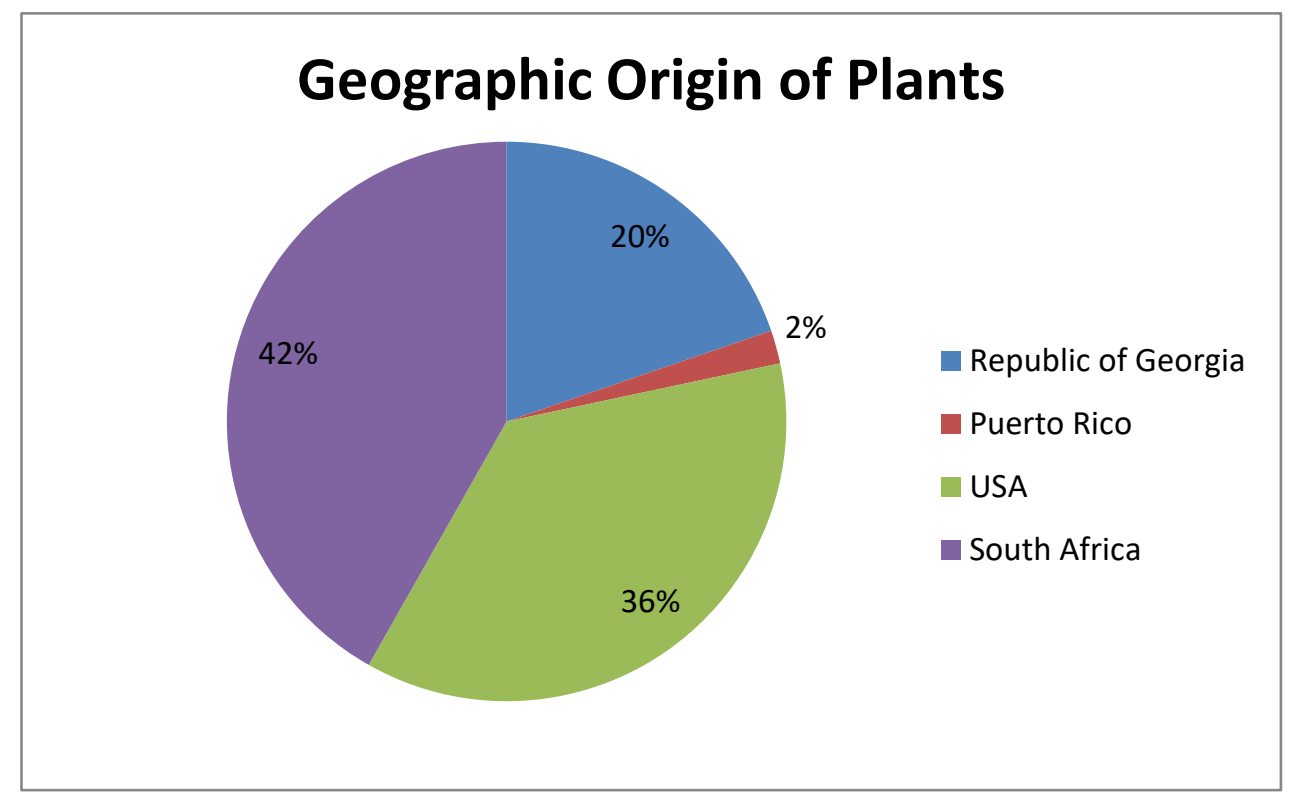

Figure 5. Geographic origin of the plants and respective percentage of use in this study.

The extraction was performed according to the following procedure: the plant material (either whole plants or separated parts) for each extract was dried and ground up into a powder. Methanol was added to each powder sample $(12 \mathrm{~mL} / \mathrm{g})$, and this was shaken for about one hour. The solvent mixture was filtered, and the filtrate was concentrated under vacuum. The concentrated extracts were transferred to amber Qorpak bottles and stored at $-20{ }^{\circ} \mathrm{C}$. The crude methanol extracts (about $2 \mathrm{~g}$ of each) were suspended in $20 \mathrm{~mL}$ of $90 \%$ aqueous methanol and washed twice with an equal volume of hexane. The hexane washes were pooled and concentrated under vacuum to yield the hexane fractions. The aqueous methanol layer was concentrated and resuspended in $20 \mathrm{~mL}$ of $50 \%$ aqueous methanol, and this was washed twice with an equal volume of dichloromethane. The dichloromethane washes were pooled and dried under vacuum to afford the dichloromethane fractions. The $50 \%$ aqueous methanol fraction was added at about 5 cc of pre-wet solid polyvinylpyrrolidone (PVP), and this was shaken for $2 \mathrm{~h}$. After centrifugation and collection of the 50\% aqueous methanol solution, the PVP was washed with $20 \mathrm{~mL}$ of methanol for $2 \mathrm{~h}$. The samples were again centrifuged, the methanol solutions were collected, and the two PVP washes were pooled and dried for each crude extract to afford the detanninized aqueous methanol fraction. For screening, solutions of the hexane, dichloromethane, and detanninized aqueous methanol fractions were prepared at $10 \mathrm{mg} / \mathrm{mL}$ in dimethyl sulfoxide (DMSO), which were later diluted for assay.

\subsection{L. monocytogenes Strain and Culture Conditions}

L. monocytogenes F2365 was used in this study; it was isolated from Mexican-style soft cheese that was implicated in an outbreak of listeriosis in the US [60]. The strain was stored in brain heart infusion (BHI) broth with $20 \%$ glycerol $(v / v)$ at $-80{ }^{\circ} \mathrm{C}$. When used in experiments, it was streaked onto BHI agar plates and incubated at $37^{\circ} \mathrm{C}$ for $24 \mathrm{~h}$. A typical colony was selected and inoculated into $5 \mathrm{~mL}$ of $\mathrm{BHI}$ and incubated at $37^{\circ} \mathrm{C}$ with shaking at $150 \mathrm{rpm}$ for $24 \mathrm{~h}$. 


\subsection{Plant Extracts Effect on L. monocytogenes Growth and Determination of MICs}

For examination of the effect of the plant extracts on L. monocytogenes, a 1:1000 dilution of the overnight culture was made with fresh BHI broth. A 96-well plate was used for testing. The wells in the first column received $190 \mu \mathrm{L}$ of BHI broth and $10 \mu \mathrm{L}$ of DMSO (negative control). Wells in the last column of the plate were used as the positive control receiving $10 \mu \mathrm{L}$ of DMSO $(0.1 \mathrm{mg} / \mathrm{mL})$ and $190 \mu \mathrm{L}$ of the diluted L. monocytogenes culture. The central wells received $10 \mu \mathrm{L}$ of the plant extract stock solution tested and $190 \mu \mathrm{L}$ of the diluted L. monocytogenes culture. The plate was placed into a microplate reader Epoch2 (BioTek, Winooski, VT, USA) and incubated at $37^{\circ} \mathrm{C}$ for $24 \mathrm{~h}$, with optical density at $600 \mathrm{~nm}\left(\mathrm{OD}_{600}\right)$ readings recorded once every hour. For each plant extract, a minimum of three replicates were performed.

The MICs for L. monocytogenes F2365 were determined using a two-fold dilution method [61] for the plant extracts that showed growth inhibition in the screening assay. Bacterial cells were treated with different concentrations of the plant extracts $(10,5,2.5,1.25,0.625,0.3125,0.156$, and $0.078 \mathrm{mg} / \mathrm{mL})$ in a 96-well plate. The wells in the first column received $190 \mu \mathrm{L}$ of BHI broth (negative control) and $0.1 \mathrm{mg} / \mathrm{mL}$ of DMSO. The final column of the plate was used as a positive control receiving $200 \mu \mathrm{L}$ of the diluted $L$. monocytogenes culture. The central wells received $10 \mu \mathrm{L}$ of the plant extract solution to test in the top row plate, two-fold diluted moving down from the top, and $190 \mu \mathrm{L}$ of the diluted L. monocytogenes culture. The plate was placed into a microplate reader Epoch2 (BioTek, VT, USA), incubated at $37^{\circ} \mathrm{C}$ for $24 \mathrm{~h}$, and $\mathrm{OD}_{600}$ readings were recorded once every hour. The lowest extract concentrations that showed no increase of $\mathrm{OD}_{600}$ over $24 \mathrm{~h}$ were determined as the MIC. Three independent experiments were performed to assess MICs.

\subsection{Scanning Electron Microscopy}

Scanning electron microscopy was used to determine how the plant extracts affected the bacteria at the microscopic level. We were able to observe the surface of the bacteria, as well as flagella production. A 5-mL culture of L. monocytogenes F2365 was supplemented with the plant extracts at MICs. The culture was incubated overnight at $30{ }^{\circ} \mathrm{C}$ at $200 \mathrm{rpm}$. One hundred microliters of the culture was pipetted onto a 12-mm microcover glass slide (Thermo Scientific Portsmouth NH, USA) and allowed to adhere for $10 \mathrm{~min}$. After $30 \mathrm{~min}, 500 \mu \mathrm{L}$ of $2.5 \%$ glutaraldehyde was added to the slide, covering the area with the bacteria, and fixation was for $30 \mathrm{~min}$. This was followed by a 30-min wash with 2-3 mL of the following solutions: $0.1 \mathrm{M}$ imidazole (two consecutive washes), 50\% ethanol, $80 \%$ ethanol, and $90 \%$ ethanol, followed by three consecutive washes with $100 \%$ ethanol. Samples were stacked into a wire basket, separated by a cloth, and placed into a critical point drying apparatus (Denton DCP-1) that used liquid carbon dioxide to completely dry the sample. The samples were removed from the critical dryer and mounted onto stubs. They were then sputter gold-coated for 1 min. Samples were finally viewed with the FEI Quanta 200 F Scanning Electron Microscope (FEI Co., INC., Hillsboro, OR, USA), with an accelerating voltage of $10 \mathrm{kV}$ in high vacuum mode. Instrumental magnification was set at $10,000 \times, 50,000 \times$, and $100,000 \times$ for imaging purposes.

\section{Conclusions}

This study showed the anti-L. monocytogenes activity of 12 extracts derived from plants originating from different countries. Results from our investigation demonstrate that these natural extracts notably inhibited L. monocytogenes growth. SEM results demonstrated that some plant extracts had a disruptive effect on the cell membrane, causing serious damage of the membrane of L. monocytogenes, as well as causing loss of flagella. Further fractionation of these extracts will provide detailed identification of the active components, with potential interesting applications as food preservatives to reduce the risk of contamination in the food industry from L. monocytogenes. 
Author Contributions: Conceptualization, Y.L. and M.C.; methodology, J.A.C., M.C., and F.Z.; resources, M.J.T. and Y.L.; writing—original draft preparation, M.C.; writing—review and editing, Y.L. and Z.H.; supervision, T.P. and A.A.; funding acquisition, Y.L. All authors have read and agreed to the published version of the manuscript.

Funding: This work was supported by the US Department of Agriculture (USDA) Agricultural Research Service National Program project 108 and Food Safety project 8072-42000-082-00D. Mention of trade names or commercial products is solely for the purpose of providing specific information and does not imply recommendation or endorsement by the US Department of Agriculture.

Acknowledgments: We would like to thank Joseph Uknalis for helping with the scanning electron microscopy. We would also like to thank Pina Fratamico for the critical reading of the manuscript. We would like to acknowledge Merck Research Laboratories for their donation of the plant collection to BSBI, and the New York Botanical Garden for coordinating plant collections and curating voucher specimens.

Conflicts of Interest: The authors declare no conflict of interest. The funders had no role in the design of the study; in the collection, analyses, or interpretation of data; in the writing of the manuscript, or in the decision to publish the results.

\section{References}

1. EFSA and ECDC (European Food Safety Authority and European Centre for Disease Prevention and Control). The European Union One Health 2018 Zoonoses Report. EFSA J. 2019, 17, 5926. [CrossRef]

2. EFSA and ECDC (European Food Safety Authority and European Centre for Disease Prevention and Control). The European Union summary report on trends and sources of zoonoses, zoonotic agents and food-borne outbreaks in 2017. EFSA J. 2018, 16, 5500. [CrossRef]

3. Allen, K.; Wałecka-Zacharska, E.; Kosek-Paszkowska, K.; Devlieghere, F.; Van Meervenne, E.; Osek, J.; Wieczorek, K.; Bania, J. Listeria monocytogenes-An examination of food chain factors potentially contributing to antimicrobial resistance. Food Microbiol. 2015, 54, 178-189. [CrossRef]

4. Bahrami, A.; Baboli, Z.M.; Schimmel, K.; Jafari, S.M.; Williams, L. Efficiency of novel processing technologies for the control of Listeria monocytogenes in food products. Trends Food Sci. Technol. 2020, 96, 61-78. [CrossRef]

5. Rothrock, M.J., Jr.; Micciche, A.C.; Bodie, A.R.; Ricke, S.C. Listeria occurrence and potential control strategies in alternative and conventional poultry processing and retail. Front. Sustain. Food Syst. 2019, 3, 33. [CrossRef]

6. Pouillot, R.; Hoelzer, K.; Jackson, K.A.; Henao, O.L.; Silk, B.J. Relative risk of listeriosis in Foodborne Diseases Active Surveillance Network (FoodNet) sites according to age, pregnancy, and ethnicity. Clin. Infect. Dis. 2012, 54, S405-S410. [CrossRef]

7. Fei, P.; Ali, M.A.; Gong, S.; Sun, Q.; Bi, X.; Liu, S.; Guo, L. Antimicrobial activity and mechanism of action of olive oil polyphenols extract against Cronobacter sakazakii. Food Control 2018, 94, 289-294. [CrossRef]

8. Araya-Cloutier, C.; Vincken, J.-P.; van Ederen, R.; den Besten, H.M.W.; Gruppen, H. Rapid membrane permeabilization of Listeria monocytogenes and Escherichia coli induced by antibacterial prenylated phenolic compounds from legumes. Food Chem. 2018, 240, 147-155. [CrossRef]

9. Guo, L.; Sun, Q.; Gong, S.; Bi, X.; Jiang, W.; Xue, W.; Fei, P. Antimicrobial activity and action approach of the olive oil polyphenol extract against Listeria monocytogenes. Front. Microbiol. 2019, 10, 1586. [CrossRef]

10. Xylia, P.; Chrysargyris, A.; Botsaris, G.; Tzortzakis, N. Mint and pomegranate extracts/oils as antibacterial agents against Escherichia coli O157:H7 and Listeria monocytogenes on shredded carrots. J. Food Safety 2018, 38, e12423. [CrossRef]

11. Germanò, M.P.; D’Angelo, V.; Sanogo, R.; Catania, S.; Alma, R.; De Pasquale, R.; Bisignano, G. Hepatoprotective and antibacterial effects of extracts from Trichilia emetica Vahl. (Meliaceae). J. Ethnopharmacol. 2005, 96, 227-232. [CrossRef]

12. Moyo, P.; Botha, M.E.; Nondaba, S.; Niemand, J.; Maharaj, V.J.; Eloff, J.N.; Louw, A.I.; Birkholtz, L. In vitro inhibition of Plasmodium falciparum early and late stage gametocyte viability by extracts from eight traditionally used South African plant species. J. Ethnopharmacol. 2016, 185, 235-242. [CrossRef]

13. Dhawan, K.; Dhawan, S. Sharma, A. Passiflora: A review update. J. Ethnopharmacol. 2004, 94, 1-23. [CrossRef]

14. Sasikala, V.; Saravanan, S.; Parimelazhagan, T. Analgesic and anti-inflammatory activities of Passiflora foetida L. Asian Pac. J. Trop. Med. 2011, 4, 600-603. [CrossRef] 
15. Bendini, A.; Cerretani, L.; Pizzolante, L.; Toschi, T.G.; Guzzo, F.; Ceoldo, S.; Marconi, A.M.; Andreetta, F.; Levi, M. Phenol content related to antioxidant and antimicrobial activities of Passiflora spp. extracts. Eur. Food Res. Technol. 2006, 223, 102-109. [CrossRef]

16. Simão, J.M.; Barboza, T.; Vianna, M.; Garcia, R.; Mansur, E.; Ignacio, A.C.; Pacheco, G. A comparative study of phytoconstituents and antibacterial activity of in vitro derived materials of four Passiflora species. An. Acad. Bras. Cienc. 2018, 90, 2805-2813. [CrossRef]

17. Sharifi-Rad, J.; Mnayer, D.; Roointan, A.; Shahri, F.; Ayatollahi, S.A.; Sharifi-Rad, M.; Molaee, N.; Sharifi-Rad, M. Antibacterial activities of essential oils from Iranian medicinal plants on extended-spectrum $\beta$-lactamase-producing Escherichia coli. Cell Mol. Biol. (Noisy-le-grand) 2016, 62, 75-82.

18. Lu, Y.; Foo, L.Y. Polyphenolics of Salvia-a review. Phytochemistry 2002, 59, 117-140. [CrossRef]

19. Cocan, I.; Alexa, E.; Danciu, C.; Radulov, I.; Galuscan, A.; Obistioiu, D.; Morvay, A.A.; Sumalan, R.M.; Poiana, M.A.; Pop, G.; et al. Phytochemical screening and biological activity of Lamiaceae family plant extracts. Exp. Ther. Med. 2018, 15, 1863-1870. [CrossRef]

20. Firuzi, O.; Miri, R.; Asadollahi, M.; Eslami, S.; Jassbi, A.R. Cytotoxic, antioxidant and antimicrobial activities and phenolic contents of eleven salvia species from Iran. Iran. J. Pharm. Res. 2013, 12, 801-810.

21. Jabbari, M.; Daneshfard, B.; Emtiazy, M.; Khiveh, A.; Hashempur, M.H. Biological Effects and Clinical Applications of Dwarf Elder (Sambucus ebulus L): A Review. J. Evid. Based Complementary Altern. Med. 2017, 22, 996-1001. [CrossRef]

22. Süntar, I.P.; Akkol, E.K.; Yalçin, F.N.; Koca, U.; Keleş, H.; Yesilada, E. Wound healing potential of Sambucus ebulus L. leaves and isolation of an active component, quercetin 3-O-glucoside. J. Ethnopharmacol. 2010, 129, 106-114. [CrossRef]

23. Schwaiger, S.; Zeller, I.; Pölzelbauer, P.; Frotschnig, S.; Laufer, G.; Messner, B.; Pieri, V.; Stuppner, H.; Bernhard, D. Identification and pharmacological characterization of the anti-inflammatory principal of the leaves of dwarf elder (Sambucus ebulus L.). J. Ethnopharmacol. 2011, 133, 704-709. [CrossRef]

24. Ebrahimzadeh, M.A.; Nabavi, S.F.; Nabavi, S.M. Antioxidant activities of methanol extract of Sambucus ebulus L. flower. Pak. J. Biol. Sci. 2009, 12, 447-450. [CrossRef]

25. Hosseinimehr, S.J.; Pourmorad, F.; Shahabimajd, N.; Shahrbandy, K.; Hosseinzadeh, R.; Pak, J. In vitro antioxidant activity of Polygonium hyrcanicum, Centaurea depressa, Sambucus ebulus, Mentha spicata and Phytolacca americana. Biol. Sci. 2007, 10, 637-640. [CrossRef]

26. Salehzadeh, A.; Asadpour, L.; Naeemi, A.S.; Houshmand, E. Antimicrobial activity of methanolic extracts of Sambucus ebulus and Urtica dioica against clinical isolates of methicillin resistant Staphylococcus aureus. Afr. J. Tradit. Complement. Altern. Med. 2014, 11, 38-40. [CrossRef]

27. Quave, C.L.; Plano, L.R.; Bennett, B.C. Quorum sensing inhibitors of Staphylococcus aureus from Italian medicinal plants. Planta Med. 2011, 77, 188-195. [CrossRef] [PubMed]

28. di Bello, I.C.; Dorling, P.; Fellows, L.; Winchester, B. Specific inhibition of human beta-D-glucuronidase and alpha-L-iduronidase by a trihydroxy pipecolic acid of plant origin. FEBS Lett. 1984, 176, 61-64. [CrossRef]

29. Nazeer, M.A.; Khoshoo, T.N. Cytology of some species of Sansevieria Thunb. Cytologia 1984, 49, $325-332$. [CrossRef]

30. Wyk, B.E.; Oudtshoorn, B.; Gericke, N. Medicinal Plants of South Africa, 2nd ed.; Briza Publications: Pretoria, South Africa, 2009.

31. Giovannini, P.; Howes, M.R. Medicinal plants used to treat snakebite in Central America: Review and assessment of scientific evidence. J. Ethnopharmacol. 2017, 199, 240-256. [CrossRef]

32. Sriprapat, W.; Boraphech, P.; Thiravetyan, P. Factors affecting xylene-contaminated air removal by the ornamental plant Zamioculcas zamiifolia. Environ. Sci. Pollut. Res. Int. 2014, 21, 2603-2610. [CrossRef]

33. Sriprapat, W.; Suksabye, P.; Areephak, S.; Klantup, P.; Waraha, A.; Sawattan, A.; Thiravetyan, P. Uptake of toluene and ethylbenzene by plants: Removal of volatile indoor air contaminants. Ecotoxicol. Environ. Saf. 2014, 102, 147-151. [CrossRef]

34. Amoateng, P.; Adjei, S.; Osei-Safo, D.; Kukuia, K.K.E.; Karikari, T.K.; Nyarko, A.K. An ethanolic extract of Desmodium adscendens exhibits antipsychotic-like activity in mice. J. Basic Clin. Physiol. Pharmacol. 2017, 28, 507-518. [CrossRef] [PubMed]

35. Awouafack, M.D.; McGaw, L.J.; Gottfried, S.; Mbouangouere, R.; Tane, P.; Spiteller, M.; Eloff, J.N. Antimicrobial activity and cytotoxicity of the ethanol extract, fractions and eight compounds isolated from Eriosema robustum (Fabaceae). BMC Complement. Altern. Med. 2013, 13, 289. [CrossRef] 
36. Awouafack, M.D.; Tane, P.; Spiteller, M.; Eloff, J.N. Eriosema (Fabaceae) species represent a rich source of flavonoids with interesting pharmacological activities. Nat. Prod. Commun. 2015, 10, 1325-1330. [CrossRef]

37. Hotti, H.; Gopalacharyulu, P.; Seppänen-Laakso, T.; Rischer, H. Metabolite profiling of the carnivorous pitcher plants Darlingtonia and Sarracenia. PLoS ONE 2017, 12, e0171078. [CrossRef]

38. Riffle, M.S.; Waller, G.R.; Murray, D.S.; Sgaramello, R.P. Devil's-claw (Proboscidea louisianica), essential oil and its components: Potential allelochemical agents on cotton and wheat. J. Chem. Ecol. 1990, 16, 1927-1940. [CrossRef]

39. Connor, S.E.; Kvavadze, E.V. Modelling late quaternary changes in plant distribution, vegetation and climate using pollen data from Georgia, Caucasus. J. Biogeogr. 2009, 36, 529-545. [CrossRef]

40. Othman, L.; Sleiman, A.; Abdel-Massih, R.M. Antimicrobial activity of polyphenols and alkaloids in middle eastern plants. Front. Microbiol. 2019, 10, 911. [CrossRef]

41. Papuc, C.; Goran, G.V.; Predescu, C.N.; Nicorescu, V.; Stefan, G. Plant polyphenols as antioxidant and antibacterial agents for shelf-life extension of meat and meat products: Classification, structures, sources, and action mechanisms. Compr. Rev. Food Sci. 2017, 16, 1243-1268. [CrossRef]

42. Okuda, T. Systematics and health effects of chemically distinct tannins in medicinal plants. Phytochemistry 2005, 66, 2012-2031. [CrossRef]

43. Bouarab-Chibane, L.; Forquet, V.; Lantéri, P.; Clément, Y.; Léonard-Akkari, L.; Oulahal, N.; Degraeve, P.; Bordes, C. Antibacterial properties of polyphenols: Characterization and QSAR (Quantitative Structure-Activity Relationship) models. Front. Microbiol. 2019, 10, 829. [CrossRef]

44. Tiwari, B.K.; Valdramidis, V.P.; O’Donnell, C.P.; Muthukumarappan, K.; Bourke, P.; Cullen, P.J. Application of natural antimicrobials for food preservation. J. Agric. Food Chem. 2009, 57, 5987-6000. [CrossRef]

45. Sultanbawa, Y. Plant antimicrobials in food applications: Minireview. In Science Against Microbial Pathogens: Communicating Current Research and Technological Advances; Mendez-Vilas, A., Ed.; Formatex Research Center: Badajoz, Spain, 2011; Volume 2, pp. 1084-1099.

46. Field, J.A.; Lettinga, G. Toxicity of tannic compounds to microorganisms. In Plant Polyphenols; Hemingway, R.W., Laks, P.E., Eds.; Springer US: London, UK, 1992; pp. 673-692.

47. Cowan, M.M. Plant products as antimicrobial agents. Clin. Microbiol. Rev. 1999, 12, 564-582. [CrossRef]

48. Kumar, S.; Pandey, A.K. Chemistry and biological activities of flavonoids: An overview. World Sci. J. 2013, 1-16. [CrossRef]

49. Kumar, Y.; Yadav, D.N.; Ahmad, T.; Narsaiah, K. Recent trends in the use of natural antioxidants for meat and meat products. Compr. Rev. Food Sci. Food Saf. 2015, 14, 796-812. [CrossRef]

50. Ikigai, H.; Nakae, T.; Hara, Y.; Shimamura, T. Bactericidal catechins damage the lipid bilayer. Biochim. Biophys. Acta. 1993, 1147, 132-136. [CrossRef]

51. Cho, Y.S.; Schiller, N.L.; Kahng, H.Y.; Oh, K.H. Cellular responses and proteomic analysis of Escherichia coli exposed to green tea polyphenols. Curr. Microbiol. 2007, 55, 501-506. [CrossRef]

52. Matsumoto, Y.; Kaihatsu, K.; Nishino, K.; Ogawa, M.; Kato, N.; Yamaguchi, A. Antibacterial and antifungal activities of new acylated derivatives of epigallocatechin gallate. Front. Microbiol. 2012, 3, 1-10. [CrossRef]

53. Nazzaro, F.; Fratianni, F.; De Martino, L.; Coppola, R.; De Feo, V. Effect of essential oils on pathogenic bacteria. Pharmaceuticals (Basel) 2013, 6, 1451-1474. [CrossRef]

54. Yi, S.; Wang, W.; Bai, F.; Zhu, J.; Li, J.; Li, X.; Xu, I.; Sun, T.; He, Y. Antimicrobial effect and membrane-activ mechanism of tea polyphenols against Serratia marcescens. World J. Microbiol. Biotechnol. 2014, 30, 451-460. [CrossRef]

55. Borges, A.; Ferreira, C.; Saavedra, M.J.; Simões, M. Antibacterial activity and mode of action of ferulic and gallic acids against pathogenic bacteria. Microb. Drug Resist. 2013, 19, 256-265. [CrossRef]

56. Liu, Y.; McKeever, C.L.; Malik, N.S.A. Assessment of the antimicrobial activity of olive leaf extract against foodborne bacterial pathogens. Front. Microbiol. 2017, 8, 113. [CrossRef] [PubMed]

57. Borges, A.; Saavedra, M.J.; Simões, M. The activity of ferulic and gallic acids in biofilm prevention and control of pathogenic bacteria. Biofouling 2012, 28, 755-767. [CrossRef]

58. Carraro, L.; Fasolato, L.; Montemurro, F.; Martino, M.E.; Balzan, S.; Servili, M.; Novelli, E.; Cardazzo, B. Polyphenols from olive mill waste affect biofilm formation and motility in Escherichia coli K-12. Microb. Biotechnol. 2014, 7, 265-275. [CrossRef]

59. Du, R.; Qu, Y.; Qi, P.X.; Sun, X.; Liu, Y.; Zhao, M. Natural flagella-templated Au nanowires as a novel adjuvant against Listeria monocytogenes. Nanoscale 2020, 12, 5627-5635. [CrossRef] 
60. Linnan, M.J.; Mascola, L.; Lou, X.D.; Goulet, V.; May, S.; Salminen, C.; Hird, D.W.; Yonekura, M.L.; Hayes, P.; Weaver, R.; et al. Epidemic listeriosis associated with Mexican-style cheese. N. Engl. J. Med. 1988, 319, 823-828. [CrossRef]

61. Balouiri, M.; Sadiki, M.; Ibnsouda, S.K. Methods for in vitro evaluating antimicrobial activity: A review. J. Pharm. Anal. 2016, 6, 71-79. [CrossRef]

(C) 2020 by the authors. Licensee MDPI, Basel, Switzerland. This article is an open access article distributed under the terms and conditions of the Creative Commons Attribution (CC BY) license (http://creativecommons.org/licenses/by/4.0/). 